\title{
OONAGH MCDONALD
}

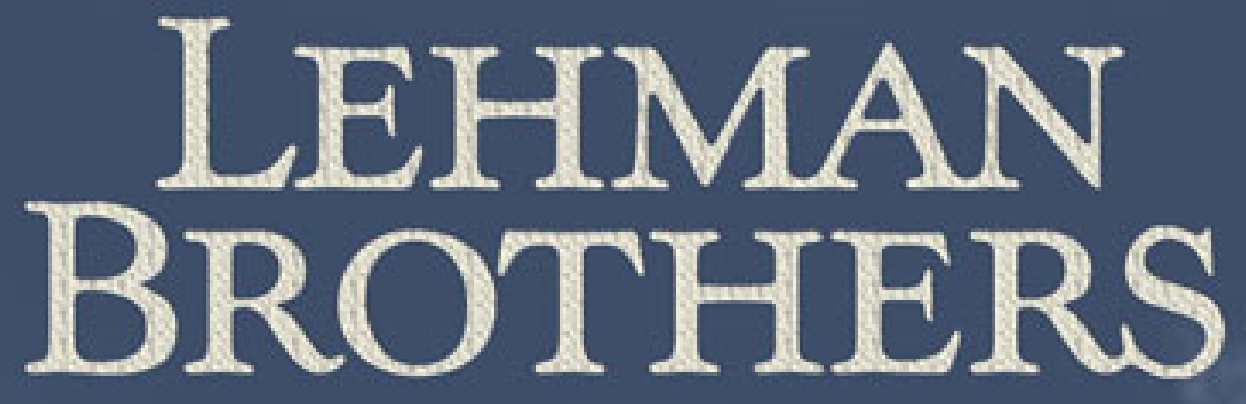

\section{A CRISIS OF VALUE}

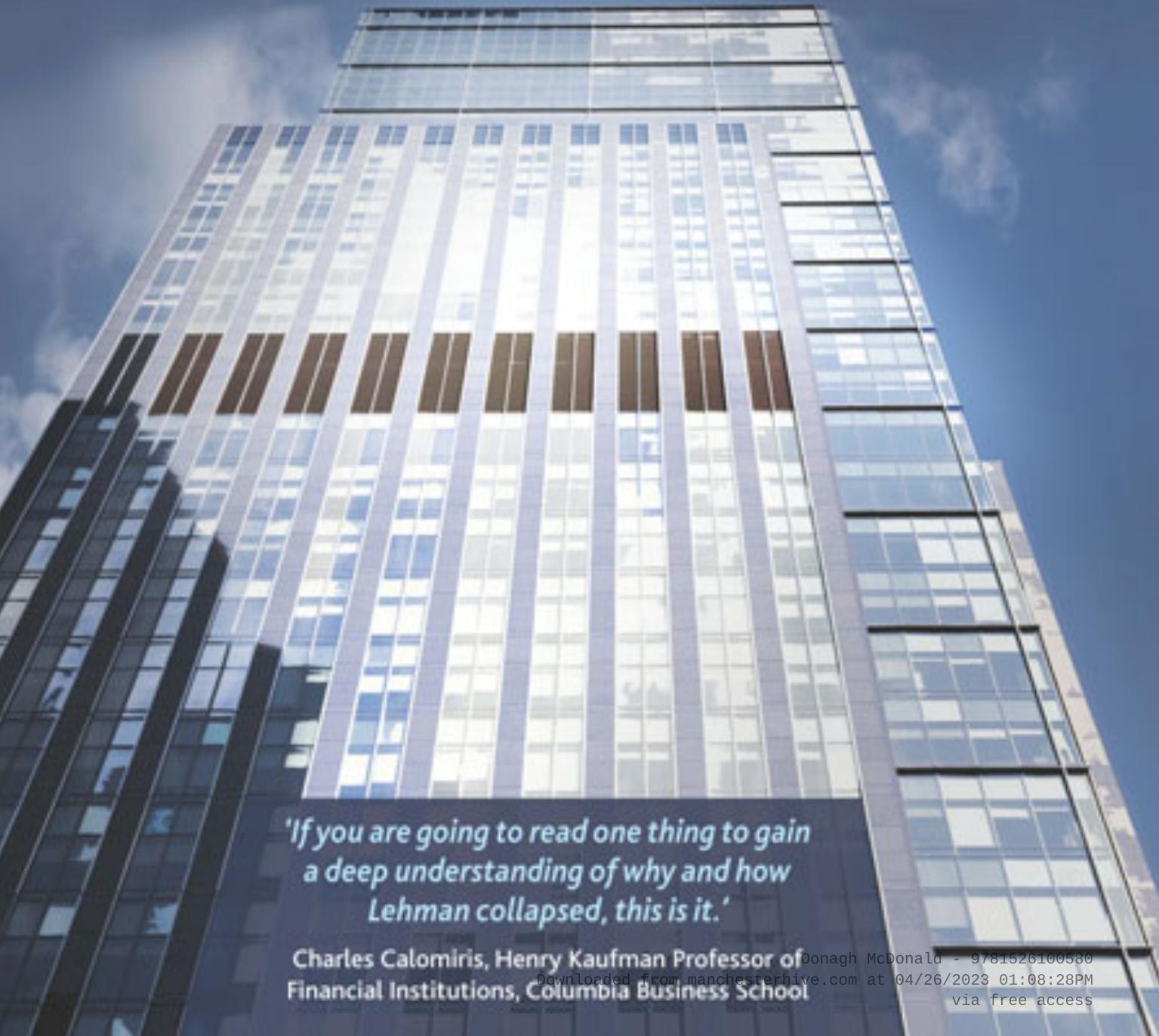




\title{
Lehman Brothers
}

\author{
A Crisis of Value
}

\section{MANCHESTER

Manchester University Press 
Oonagh McDonald - 9781526100580 Downloaded from manchesterhive.com at 04/26/2023 01:08:28PM via free access 


\title{
Lehman Brothers
}

\author{
A Crisis of Value
}

Oonagh McDonald

Manchester University Press 


\title{
Copyright @ Oonagh McDonald 2016
}

The right of Oonagh McDonald to be identified as the author of this work has been asserted by her in accordance with the Copyright, Designs and Patents Act 1988.

\author{
Published by Manchester University Press \\ Altrincham Street, Manchester M1 7JA \\ www.manchesteruniversitypress.co.uk
}

\section{(ㅇ)(1) $\odot \Theta$}

This work is published subject to a Creative Commons Attribution Non-commercial No Derivatives Licence. You may share this work for non-commercial purposes only, provided you give attribution to the copyright holder and the publisher. For permission to publish commercial versions please contact Manchester University Press.

\author{
British Library Cataloguing-in-Publication Data \\ A catalogue record for this book is available from the British Library
}

Library of Congress Cataloging-in-Publication Data applied for

ISBN 9781784993405 hardback

ISBN 9781526100580 open access

First published 2016

The publisher has no responsibility for the persistence or accuracy of URLs for any external or third-party internet websites referred to in this book, and does not guarantee that any content on such websites is, or will remain, accurate or appropriate.

\section{Typeset by}

RefineCatch Limited, Bungay, Suffolk 